\title{
The anti-inflammatory effect of Colocasia esculenta water extract on mouse ear edema models induced by TPA
}

\author{
Dong Woo Kang ${ }^{1}$, Soo Cheol Choi ${ }^{2}$, Jeong Eun Kang ${ }^{1}$, Ji Sun Park ${ }^{3}$, and In Ah Lee ${ }^{4^{*}}$ \\ ${ }^{1}$ Master program in Chemistry, Kunsan National University, Gunsan 54150, Korea \\ ${ }^{2}$ Doctoral program in Chemistry, Kunsan National University, Gunsan 54150, Korea \\ ${ }^{3}$ Master, Department of Chemistry, Kunsan National University, Gunsan 54150, Korea \\ ${ }^{4}$ Professor, Department of Chemistry, Kunsan National University, Gunsan 54150, Korea
}

\section{ABSTRACT}

Background and objective: Dermatitis is a chronic disease accompanied by such symptoms as itching and dry skin. The environment and diet can aggravate dermatitis, so attention to skin care is essential. Colocasia esculenta is used in various manners and for different purposes, including with regard to inflammation, aging, and the digestive system. The anti-inflammatory effect of Colocasia esculenta water extract was confirmed using RAW 264.7 macrophages with regard to male ICR mice.

Methods: In the case of the ICR mice, 5\% 12-0-Tetradecanoylphorbol-13-acetate (TPA) was used to cause inflammation for 7 days, and $100 \mu \mathrm{L}$ of Colocasia esculenta water extract and panthenol were administered orally for 10 days. In addition, RT-PCR, NO, ELISA was conducted.

Results: As a result of reverse transcription polymerase chain reaction (RT-PCR) using RAW 264.7 macrophages stimulated with lipopolysaccharide (LPS), it was found that Colocasia esculenta water extract reduced the expression of inflammatory cytokines. As a result of hematoxylin and eosin (H\&E) staining using mouse ear tissue, Colocasia esculenta water extract reduced ear thickness and showed an effect of suppressing ear edema. In addition, compared to the TPA-treated group, the Colocasia esculenta extract-treated group had reduced nitric oxide (NO) production by $18.23 \mu \mathrm{M}$ and IL-13 production decreased by $136.55 \mathrm{pg} / \mathrm{ml}$.

Conclusion: Colocasia esculenta water extract has been shown to be effective in lowering inflammatory cytokine production. These results suggest that Colocasia esculenta water extracts can be used as natural products to treat dermatitis.

Keywords: cytokines, dermatitis, panthenol, pruritus, skin

\section{Introduction}

Dermatitis is a disease that lowers the quality of human life as it causes such symptoms as inflammation of the skin as a result of internal or external factors. Dermatitis is a chronic inflammatory skin disease with itching and dry skin (Xeroderma) as the main symptoms. Atopic dermatitis requires that special attention be paid to the environment and diet, and also requires that particular attention be given to skin care management. Dermatitis generally develops due to congenital or acquired causes, and an exact treatment for atopic dermatitis that develops due to these two causes has not yet been found. As dysfunctions have been reported due to long-term use of chemically synthesized drugs and their side effects, efforts have been made to develop natural medicines with fewer side effects that also have anti-inflammatory properties (Noh et al., 2017). Inflammation is a defense action of a living body against

This research was supported by funds of National Research Foundation (NRF-2019R1A4A1026423).

Received: December 29, 2020, Revised: January 5, 2021, Accepted: January 5, 2021

First author: Dong woo Kang, szer789@naver.com, (1) https://orcid.org/0000-0001-8113-4251

*Corresponding author: In Ah Lee, leeinah@kunsan.ac.kr, (1) https://orcid.org/0000-0003-1092-471X 
external stimuli, and begins with the expression of immune cells and inflammatory mediators that are activated by external stimulants. However, inflammatory mediators cause symptoms such as redness, fever, swelling, pain, and dysfunction during the inflammatory response, worsening the condition of the disease or inducing new diseases. Therefore, control of the inflammatory response is very important in the treatment of inflammatory diseases.

Enzymes and factors that promote inflammatory responses in vivo include: cyclooxygenase-2 (COX-2) expressed by stimulation of inflammatory responses and which is also involved in cell proliferation; tumor necrosis factor- $\alpha$ (TNF- $\alpha$ ), a type of cytokine secreted by many cells such as activated macrophages and tumor cells; interleukin-6 (IL-6) secreted by stimulating the immune response of macrophages and which is also associated with inflammation; and interleukin-1 $\beta$ (IL-1 $\beta$ ), a pro-inflammatory or anti-inflammatory cytokine. These enzymes and factors produce reactive oxygen species (ROS) as well as inflammation. Excessive ROS are the cause of various inflammatory skin diseases such as atopic dermatitis, and since inflammation is also involved in various intractable diseases, substances that inhibit them are highly likely to be developed as anti-inflammatory agents (Agyare et al., 2016; Song, et al., 2008).

Among nature-friendly materials, Colocasia esculenta (taro), in particular, is a herbaceous perennial of the family Araceae, which is widely cultivated in tropical and temperate regions, with 100 genera and 1,500 varieties distributed worldwide (Noh et al., 2017). Edible Colocasia esculenta includes the genera Colocasia and Xanthosoma, and the species C.esculenta is the best known. Colocasia esculenta has the lowest calorie content among bulbs, and its main component is starch, except for $70-83 \%$ moisture, and contains dextrin and sucrose, giving it its own sweet taste, as well as galactan, a sticky mucous component. Among the different types of potatoes, it contains relatively a lot of protein and is rich in essential amino acids and dietary fiber. In addition, it is rich in minerals such as potassium, phosphorus, and calcium, and vitamin $\mathrm{C}$, so it has high nutritional value as a famine relief crop. Traditionally in Korean medicine, Colocasia esculenta has been used to lower body heat and relieve inflammation because of its excellent anti-inflammatory effect (Caicedo et al., 2018; Rashmi et al., 2018). It contains several ingredients such as galactan (prevents cardiovascular disease), melatonin (natural sleep aid), and mutin (protects the stomach). Among such ingredients, a component called panthenol has been reported to be excellent in terms of its anti-inflammatory effects on the skin, and is known to be effective in treating various skin diseases (Aruna et al., 2009; Caicedo et al., 2018; Muñoz-Cuervo et al,. 2016; Ogata and Makisumi, 1984, 1985; Rashmi et al., 2018). Panthenol comes either in $\mathrm{D}$ form or as a racemic mixture of $\mathrm{D}$ and $\mathrm{L}$, and L-panthenol is not biologically active, so only D-panthenol is converted to $\mathrm{B}_{5}$ (Vitamin $\mathrm{B}_{5}$ ). Panthenol, a precursor of pantothenic acid, changes to pantothenic acid through a chemical reaction when absorbed into the body, and acetyl coenzyme A (acetyl-CoA) produces ATP through the Krebs cycle. Using the generated ATP, the basal cells of the base layer, the lowest layer of the skin, are created to regenerate the skin. In addition, panthenol acts on the adrenal cortex to promote hormone secretion, keeping the digestive and nervous systems healthy, and helps improve acne and skin problems (Andrieux et al., 2012; Lomenova et al., 2018; Kelly, 2011; Tahiliani and Beinlich, 1991).

Therefore, using the nutritional components and physicochemical properties of Colocasia esculenta water extract, this study evaluated the anti-inflammatory activity by confirming the improvement effect of the extract on ear edema models in mice induced by 12-O-Tetradecanoylphorbol13-acetate (TPA).

\section{Research Methods}

\section{Preparation of Colocasia esculenta water extract}

The taros used in this study were obtained from Majangmyeon, Icheon-si, Gyeonggi-do. The peeled taros were washed with water, finely cut into pieces of 1 to $3 \mathrm{~cm}$ in diameter and $1 \mathrm{~cm}$ in thickness, and dried. The dried taros were pulverized into fine powder using a grinder (HR-2860, PHILIPS, Korea), and $30 \mathrm{~g}$ of a Colocasia esculenta powder sample was mixed with $800 \mathrm{ml}$ of D.W to make a mixed solution. Low temperature extraction was 
applied to the mixed solution at $40^{\circ} \mathrm{C}$ for 24 hours. The obtained extract was filtered under reduced pressure to remove impurities, and then lyophilized to obtain $5.8 \pm 0.3 \mathrm{~g}$ of a final Colocasia esculenta water extract in powder form.

\section{Cell culture}

RAW 264.7 cells, a mouse macrophage cell line were purchased from the Korea Cell Line Bank (KCLB 40071) and used. The cells were cultured in an incubator set to $5 \% \mathrm{CO}_{2}$ at $37^{\circ} \mathrm{C}$ and using dulbecco's modified eagle medium (DMEM) containing 10\% fetal bovine serum (FBS) and $1 \%$ penicillin/streptomycin.

\section{Cell viability measurement}

A crystal violet assay was used to determine the cell viability. Raw 264.7 macrophages were dispensed in an equal amount into a 24-well plate and cultured in an incubator set to $5 \% \mathrm{CO}_{2}$ at $37^{\circ} \mathrm{C}$ for 24 hours using DMEM. Thereafter, the cultured cells were further cultured for 24 hours after treatment with various concentrations of Colocasia esculenta water extract. After removing dead cells by washing the cultured cells with 1X PBS (phosphate buffer saline), the living cells were fixed using formalin and stained for 10 minutes using $1 \%$ crystal violet solution. Crystal violet stained in cells was dissolved with 33\% acetic acid, and the solution was transferred to a 96-well plate and its absorbance was measured at $595 \mathrm{~nm}$ (Tuse et al., 2009), (Kawase et al., 2003; Kim et al., 2010).

Cell viability $(\%)=$ sample absorbance $/$ control absorbance x100

\section{Reverse Transcription Polymerase Chain Reaction (RT-PCR)}

RAW 264.7 cells were dispensed into a 24-well plate at $1 \times 106$ cells, precultured for 24 hours, and treated with $1 \mu \mathrm{g} / \mathrm{mL}$ of lipopolysaccharide (LPS) and various concentrations of Colocasia esculenta water extract. The treated cells were incubated for 24 hours in a $37^{\circ} \mathrm{C}$ incubator containing 5\% $\mathrm{CO} 2$ and then the supernatant was removed and washed twice with 1X PBS. After that, RNA was extracted from the cells using a TRIzol reagent (sigma, USA), and the extracted RNA was dissolved in diethyl pyrocarbonate water $\left(\mathrm{DEPC}-\mathrm{H}_{2} \mathrm{O}\right)$ and used. After synthesizing cDNA from mRNA using an RT-PCR kit containing DNA polymerase, buffer, dNTP, and tracking dye, RT-PCR was performed for a total of 35 cycles of $30 \mathrm{sec}$ at $94^{\circ} \mathrm{C}$ followed by $30 \mathrm{sec}$ at $55-62^{\circ} \mathrm{C}$ and $1 \mathrm{~min}$ at $72^{\circ} \mathrm{C}$, using primers corresponding to IL-6, and TNF- $\alpha$, iNOS, COX-2, and $\beta$-actin genes. PCR products were confirmed by electrophoresis on $1.5 \%$ agarose gel, and for quantitative comparison, the amount of gene expression was quantified using $\beta$-actin expression as a control (Table 1) (Mler et al., 2002).

Table 1. Primer of PCR products with each primer pair

\begin{tabular}{|c|c|c|}
\hline Gene & Forward/Reverse & Sequeneces $\left(5^{\prime}-3^{\prime}\right)$ \\
\hline \multirow{2}{*}{$\mathrm{TNF}-\alpha$} & $\mathrm{F}$ & 5'-AAGTTCCCAAATGGCCTCCC-3' \\
\hline & $\mathrm{R}$ & 5'-TGGCACCACTAGTTGGTTGTCTTT-3' \\
\hline \multirow{2}{*}{ COX-2 } & $\mathrm{F}$ & 5'-CGGGTAAGCATTGTTCCTGA-3' \\
\hline & $\mathrm{R}$ & 5'-AGATGAACCTAAAACCCTTCCT-3' \\
\hline \multirow{2}{*}{ IL-1 $\beta$} & $\mathrm{F}$ & 5'-TGCAGAGTTCCCCAACTGGTACATC-3' \\
\hline & $\mathrm{R}$ & 5'-GTGCTGCCTAATGTCCCCTTGAATC-3' \\
\hline \multirow{2}{*}{ iNOS } & $\mathrm{F}$ & 5'-GGCAGCCTGTGAGACCTTTG-3' \\
\hline & $\mathrm{R}$ & 5'-GCATTGGAAGTGAAGCGTTTC-3' \\
\hline \multirow{2}{*}{ IL-6 } & $\mathrm{F}$ & 5'-CAAGAAAGACAAAGCCAGAGTCCTT-3' \\
\hline & $\mathrm{R}$ & 5'-TGGATGGTCTTGGTCCTTAGCC-3' \\
\hline \multirow{2}{*}{$\beta$-Actin } & $\mathrm{F}$ & 5'-GGACAGTGAGGCCAGGATGG-3' \\
\hline & $\mathrm{R}$ & 5'-AGTGTGACGTTGACATCCGTAAAGA-3' \\
\hline
\end{tabular}




\section{Experimental animals and grouping of experimental animals}

As for the experimental animals, 4-week-old male ICR mice were provided from Orient Bio (KOR) and used. The mice were supplied with sterilized bedding materials and solid feed in a breeding room where the temperature was maintained at $20-22^{\circ} \mathrm{C}$, humidity $40-50 \%$, and under a light-dark cycle of 12 hours with lights, and they were acclimated while freely ingesting food and water. Mice were randomly classified into 6 groups, and 6 per group: normal group; control group; 2 groups treated with $50 \mathrm{mg} / \mathrm{kg}$ and $100 \mathrm{mg} / \mathrm{kg}$ Colocasia escenta extract, respectively; 2 groups treated with $10 \mathrm{mg} / \mathrm{kg}$ and $50 \mathrm{mg} / \mathrm{kg}$ panthenol, respectively. Colocasia escenta and panthenol extracts were prepared using distilled water, and $100 \mu \mathrm{L}$ was administered orally at the same time every day for 10 days. To induce inflammatory dermatitis, 5\% TPA dissolved in distilled water was applied to the ears of the inflammationinduced group and the experimental group, except for the normal group, for 10 days after 7 days of an adaptation period. TPA, also called phorbol 12-myristate 13-acetate (PMA), is used as a tumor promoter for skin carcinogenesis in rodents, and causes cell proliferation of malignant cells in several types of tumors, such as melanoma, breast cancer and oral cancer (He et al., 2014; Takahashi et al., 2017). During the experiment, the inflammatory response of the ears and the degree of improvement of the inflammation were observed. This experiment was conducted with the approval of the Animal Experiment Ethics Committee of Kunsan National University (Table 2).

\section{Ear thickness measurement}

The ear tissues of the mouse models were excised, and the thickness was measured using a vernier caliper. In order to minimize the error in measuring the ear tissue, the ear tissues were placed in a straight line with the bottoms as a baseline for measurement, and then measured uniformly.

\section{Immunochemical tissue staining using mouse ear tissue}

Paraffin blocks of the ear tissues was prepared. The paraffin embedded tissue block was sectioned using a microtome, and cut sections were transferred to slides, and then tissue slides were soaked in xylene solution 3 times for 5 minutes to remove paraffin. After that, they were sequentially immersed in $100 \%, 95 \%$, and $70 \%$ ethanol and washed with running water for 10 minutes. In order to make the tissues blue, they were stained with haematoxylin solution for about 5minutes and washed with running water. The haematoxylin was removed from the cytoplasm using $1 \% \mathrm{HCl}$ solution and $1 \%$ ammonia solution, and the cytoplasm was stained by immersing the specimens in Eosin solution for 2 minutes. After the specimens were dehydrated by immersing in $70 \%, 95 \%$, and $100 \%$ ethanol in sequence, they were immersed in fresh xylene solution three times for 3 minutes, and then sealed with a cover glass (Fischer et al., 2008)

\section{Measurement of nitric oxide production}

This experiment was carried out according to the manufacturer's protocol of the Nitric Oxide (NO) assay kit. 50 $\mu \mathrm{L}$ of serum obtained from the mouse models was dispensed to a well plate, and then $50 \mu \mathrm{L}$ of $1 \mathrm{X}$ phosphate buffer saline (PBS) was added. After that, $50 \mu \mathrm{L}$ of Griess A and $50 \mu \mathrm{L}$ of Griess B was added to the specimen and it was incubated for 10 minutes at room temperature,

Table 2. Mouse groups classification according to sample processing

\begin{tabular}{|c|c|c|}
\hline Group $(n=6)$ & TPA-induced & Oral Administration \\
\hline Normal & - & - \\
\hline TPA & + & - \\
\hline extracts $50 \mathrm{mg} / \mathrm{kg}$ & + & + \\
\hline extracts $100 \mathrm{mg} / \mathrm{kg}$ & + & + \\
\hline panthenol $10 \mathrm{mg} / \mathrm{kg}$ & + & + \\
\hline panthenol $50 \mathrm{mg} / \mathrm{kg}$ & + & + \\
\hline
\end{tabular}


and the absorbance was measured at 550nm using a micro plate reader.

\section{IL-13 Measurement Using ELISA kit}

After X PBS was added to part of the ear tissue obtained from the animal model and crushed with a homogenizer, the protein was quantified using bradford solution, and then IL-13 was measured with an ELISA kit (Young In. Co. Seo, Korea) according to the experimental method provided by the manufacturer. After dispensing $100 \mu \mathrm{L}$ of the quantified specimen to a 96 well plate, the specimen was incubated for 2 hours in a $37^{\circ} \mathrm{C}$ incubator containing $5 \%$ $\mathrm{CO}_{2}$, and then $100 \mu \mathrm{L}$ of a secondary antibody was added and it was incubated for 1 hour at $37^{\circ} \mathrm{C}$. Thereafter, 100 $\mu \mathrm{L}$ of a color developing reagent was added and it was incubated at $37^{\circ} \mathrm{C}$ for 30 minutes, and $100 \mu \mathrm{L}$ of substrate was added for it to react at room temperature for 10 minutes. After adding $100 \mu \mathrm{L}$ of stop solution to it to terminate the reaction, the absorbance was measured at 450 nm using a micro plate reader.

\section{Statistical processing}

Experimental rests were expressed as mean \pm standard deviation (mean $\pm \mathrm{SD}$ ), and statistically significant differences were determined to be significant by t-test when ${ }^{*} p<.05,{ }^{* *} p<.01,{ }^{* * *} p<.001$.

\section{Results and Discussion}

\section{Cellar viability}

The experimental groups treated with different concentrations of Colocasia escenta water extract showed a decrease in cell viability as the concentration approaches the maximum concentration. When comparing the control group treated with 0 concentration and ones treated with maximum concentration, there was no significant difference in cell viability, and it was determined that the Colocasia escenta water extract did not significantly affect cell death (Fig. 1).

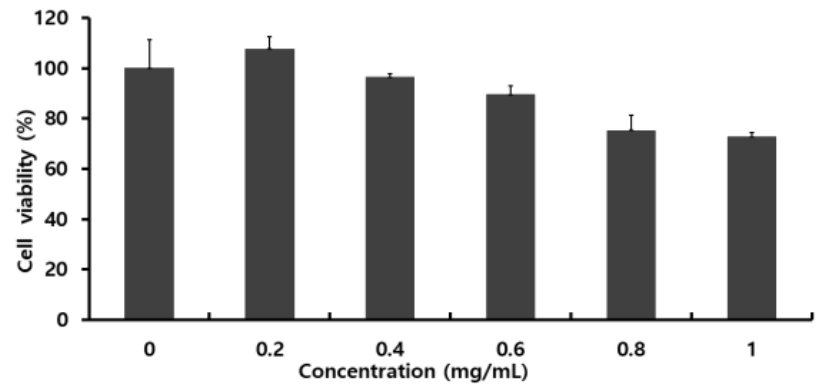

Fig. 1. Effect of Colocasia escenta water extracts on cell viability in RAW 264.7 cells. The viability of untreated control cells was defined as $100 \%$. the data was treated by increasing the concentration of Colocasia escta water extracts. (Significant as compared to control. ${ }^{*} p<.05$ )

\section{Confirmation of inflammatory cytokine expression in RAW 264.7 cells}

Reverse transcription polymerase chain reaction (RT-PCR) was used to confirm the effect of Colocasia escenta water extract on the expression of inflammatory cytokines in inflammation-induced RAW 264.7 cells. Inflammation was induced by using lipopolysaccharide (LPS), the major components of the cell wall of Gram negative bacteria, and $\beta$-acitn was used as a reference gene. As a rest, compared with the inflammation-induced groups, it was found that the higher the concentration of the Colocasia escenta water extract which the mouse models were treated with, the lower the inflammatory cytokine expression level. There was a noticeable difference in IL-6 levels compared to other genes, but there was no significant difference in IL-1 $\beta$ levels. In most of the genes, through comparison with the inflammation-induced groups, the anti-inflammatory effect on the cells of Colocasia escenta water extract and the reduction of cytokine expression were confirmed (Fig. 2). These rests suggest that Colocasia escenta water extract inhibits the expression of various inflammation-related genes including TNF- $\alpha$ and COX-2.

\section{The thickness of ear tissues of experimental animals}

The allergic ear thickness of the TPA-induced ear edema group was $0.405 \pm 0.006 \mathrm{~mm}$, which was about 1.5 times thicker compared to the normal group. The thickness of the groups treated with $50 \mathrm{mg} / \mathrm{kg}$ and $100 \mathrm{mg} / \mathrm{kg}$ of Colocasia escenta extract were $0.268 \pm 0.007 \mathrm{~mm}$, and 


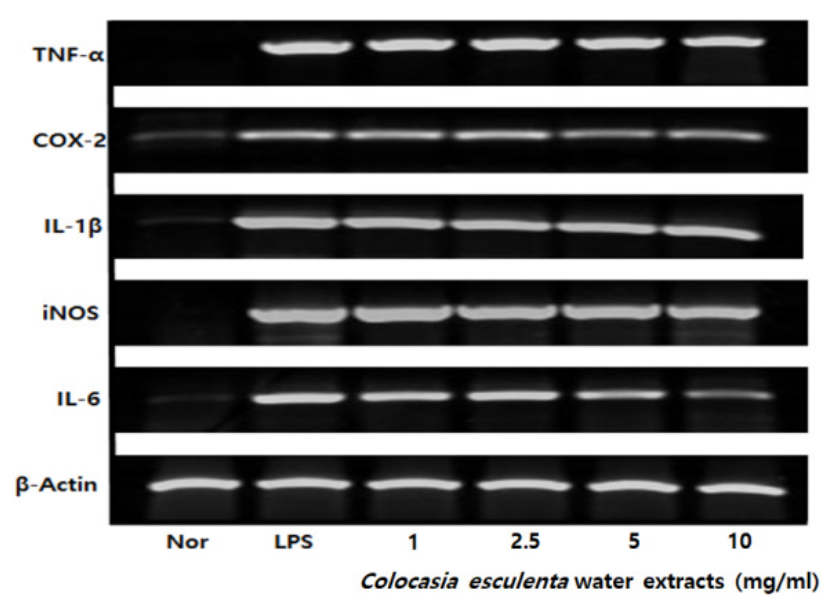

Fig. 2. Effect of extracts on the mRNA of TNF- $\alpha$, COX-2, IL-1 $\beta$, iNOS and IL-6 in RAW 264.7 cells. RAW 264.7 cells were treated with various concentrations $(1,2.5,5$ and $10 \mathrm{mg} / \mathrm{ml}$ ) of Colocasia escenta water extracts or LPS for $24 \mathrm{~h}$. Total RNA was isolated and quantified by beta-actin for quantitative comparison and expressed as a comparative graph, and the level of mRNA expression of TNF- $\alpha, \mathrm{COX}-2, \mathrm{IL}-1 \beta$, iNOS and IL -6 were measured by $R T-P C R$.

$0.272 \pm 0.012 \mathrm{~mm}$, respectively; the thickness of groups treated with $10 \mathrm{mg} / \mathrm{kg}$ and $50 \mathrm{mg} / \mathrm{kg}$ of panthenol were $0.285 \pm 0.016 \mathrm{~mm}$ and $0.285 \pm 0.010 \mathrm{~mm}$, respectively. It was confirmed that the skin damage of the allergic ear tissue induced by TPA was improved as the ear thickness of the experimental groups decreased to a level similar to that of the normal group (Fig. 3).

\section{Haematoxylin and eosin (H\&E) staining}

Haematoxylin and eosin (H \& E) staining has been used to recognize various tissue types and morphological changes that form the basis of cancer diagnosis. The staining provides a comprehensive picture of cytoplasmic, nuclear and extracellar matrix features. Hematoxylin has a deep blue purple color and stains nucleic acids, while eosin is pink and stains proteins. In tissues, nuclei are stained blue while cytoplasm and extracellar matrix are stained pink. Using this, the ear tissue of each model was stained and observed.

The improvement effects of Colocasia escenta water extract and panthenol on TPA-induced inflammation were investigated through $H \& E$ staining of the ears of each mouse group. When the ear tissues were stained with haematox-

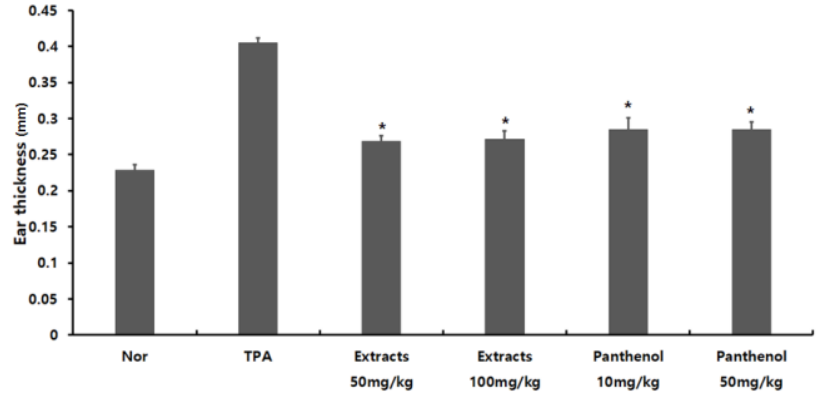

Fig. 3. Effect of TPA on allergic ear tissue reaction in ICR mouse. Inhibition of TPA-induced ear edema by topically application of Colocasia escenta water extracts was analyzed by measuring changes in ear thickness. normal group; Nor, TPA apply group; TPA, TPA + extracts $50 \mathrm{mg} / \mathrm{kg}$ : Extracts $50 \mathrm{mg} / \mathrm{kg}$, TPA + extracts $100 \mathrm{mg} / \mathrm{kg}$ : Extracts $100 \mathrm{mg} / \mathrm{kg}$, TPA + panthenol $10 \mathrm{mg} / \mathrm{kg}$ : Panthenol 10 $\mathrm{mg} / \mathrm{kg}$, TPA + panthenol $50 \mathrm{mg} / \mathrm{kg}$ : Panthenol $50 \mathrm{mg} / \mathrm{kg}$ (Significant as compared to control. ${ }^{*} p<.05$ ).

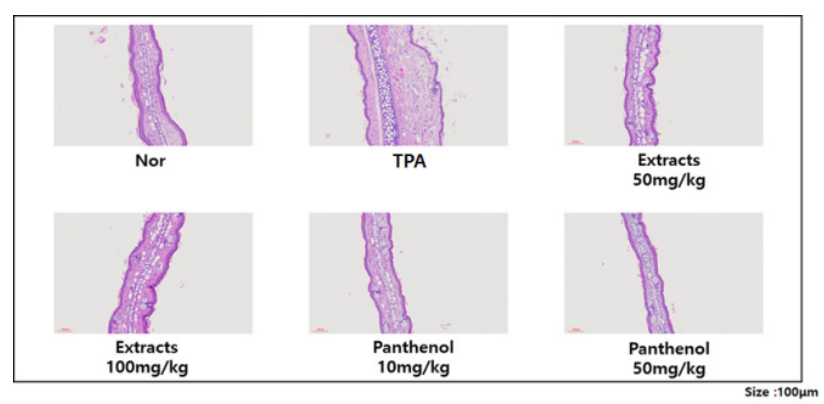

Fig. 4. Measurement of the ear thickness of TPA-induced mouse ear tissue edema. Histological microphotograph of ear tissue TPA-induced mouse (H\&E stain. $\times 100)$. normal group; Nor, TPA apply group; TPA, TPA + extracts $50 \mathrm{mg} / \mathrm{kg}$ : Extracts $50 \mathrm{mg} / \mathrm{kg}$, TPA + extracts $100 \mathrm{mg} / \mathrm{kg}$ : Extracts $100 \mathrm{mg} / \mathrm{kg}$, TPA + panthenol $10 \mathrm{mg} / \mathrm{kg}$ : Panthenol $10 \mathrm{mg} / \mathrm{kg}$, TPA + panthenol $50 \mathrm{mg} / \mathrm{kg}$ : Panthenol $50 \mathrm{mg} / \mathrm{kg}$.

ylin and eosin and visually observed, it was confirmed that the TPA-induced ear edema group had significantly thicker ears, and the ears of the Colocasia escenta water extract or panthenol-treated groups became thinner compared to the TPA-induced group, which was consistent with the rest of ear thickness measured with a vernier caliper (Fig. 4).

\section{Confirmation of nitric oxide production}

Nitric oxide (NO) regates a variety of biological processes including vascar relaxation, neuronal communication, and immune cell function. Since NO is easily oxidized into nitrate and nitrite ions in the body, the level of nitric oxide 


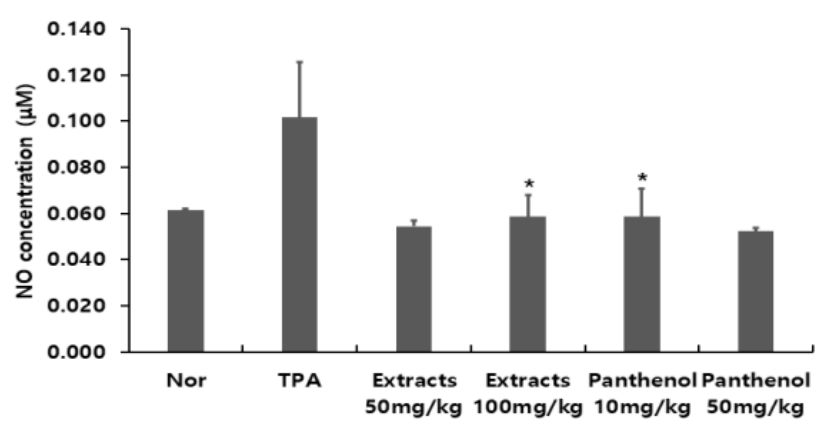

Fig. 5. Effects of Colocasia escenta water extracts on NO production. The serum were pre-treated with the various concentrations of Colocasia escenta water extracts and panthenol. the amounts of NO were determined by griess assay. (Significant as compared to control. ${ }^{*} p<.05$ )

is generally evaluated by the concentration of nitrate and nitrite ions determined through measuring absorbance (Madasamy et al., 2014).

A Giress assay was performed to measure the production of NO, a pro-inflammatory mediator in mouse blood. The amount of NO production was calcated by preparing the NO standard curve. It was confirmed that the amount of $\mathrm{NO}$ production in the normal group was $24.62 \pm 0.23 \mathrm{mM}$, and that in the TPA-induced ear edema group was increased to $40.62 \pm 9.60 \mathrm{mM}$. Those of the Colocasia escenta water extract and panthenol-treated groups were $21.82 \pm 0.92 \mathrm{mM}, 23.42 \pm 3.80 \mathrm{mM}, 23.42 \pm 4.93 \mathrm{mM}$, and $20.89 \pm 0.61 \mathrm{mM}$, respectively, indicating that the inflammatory response was induced by TPA. It was confirmed that administration of Colocasia escenta water extract showed anti-inflammatory effects by inhibiting NO production (Fig. 5).

\section{Confirmation of IL-13 production in mouse ear tissue}

Interleukin-13 (IL-13) is a central regator in IgE synthesis, and causes allergic inflammation such as mucus hypersecretion and fibrosis, and different diseases including asthma (Clark et al., 1986).

As a rest of evaluating the amount of IL-13 production in the ear tissues, the level of $418.4 \pm 3 \mathrm{pg} / \mathrm{ml}$ produced in the TPA-induced group was about 1.46 times higher compared to the normal group, and $260.1 \pm 60 \mathrm{pg} / \mathrm{ml}$ produced in the $10 \mathrm{mg} / \mathrm{kg}$ panthenol-treated group was the

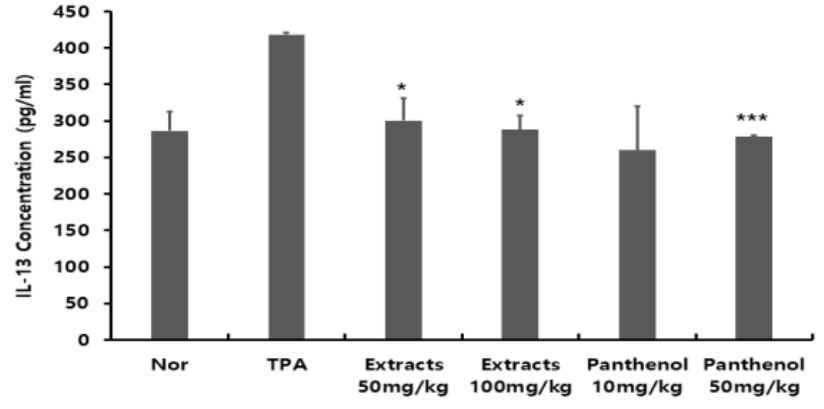

Fig. 6. The effect of Colocasia escenta water extracts on inflammatory-induced IL-13 cytokine induction. IL-13 were analyzed by ELISA. the rests revealed decreased production of IL-13 in the Colocasia escenta water extracts treated group as compared to the TPA groups. (Significant as compared to control. $\left.{ }^{*} p<.05,{ }^{* *} p<.01,{ }^{* * *} p<.001\right)$

lowest rate of production. IL-13 production in the $50 \mathrm{mg} / \mathrm{kg}$ panthenol-treated group was $278.8 \pm 1 \mathrm{pg} / \mathrm{ml}$; and the groups treated with $50 \mathrm{mg} / \mathrm{kg}$ and $100 \mathrm{mg} / \mathrm{kg}$ of Colocasia escenta extract produced $300.6 \pm 26 \mathrm{pg} / \mathrm{ml}$ and $287.9 \pm$ $19 \mathrm{pg} / \mathrm{ml}$, respectively, showing that the IL-13 levels decreased to a level similar to that of the normal group. This substantiates the supposition that Colocasia escenta water extract and panthenol components have an inhibitory effect on IL-13 (Fig. 6).

\section{Conclusion}

The economy and society have been developing rapidly, and the life expectancy is being extended with the development of medicine, but the surrounding environment is becoming polluted.

Skin with an activated immune response secretes various inflammatory cytokines, inducing the penetration of immune cells such as lymphocytes and macrophages into the epidermis or dermis. In this study, colocasia escenta, a natural product, was used for dermatitis, a skin complaint that negatively affects quality of human life. We sought to confirm the effect of Colocasia escenta on dermatitis by using a panthenol component known to be effective against inflammation as a control. To confirm the anti-inflammatory activity of Colocasia escenta water extract, RT-PCR was performed using RAW 264.7 cells, and the anti-inflammatory activity was evaluated through NO assay 
and ELISA kits.

As a rest of evaluating the anti-inflammatory effect of Colocasia escenta water extract in this study, it was shown that Colocasia escenta water extract reduced the production of inflammatory cytokines. These rests reveal that as the concentration of Colocasia escenta water extract increases $(0.2,0.4,0.6,0.8$ and $1 \mathrm{mg} / \mathrm{mL})$, the anti-inflammatory effects also increase. This suggests that Colocasia escenta water extract is a natural product that has the potential to treat atopic skin conditions as it produces an anti-inflammatory action even in atopic skin lesions.

Panthenol, used as a control in the study, is well known as an effective substance for treating inflammation. When comparing the overall rests, the panthenol-treated groups and the Colocasia escenta water extract-treated groups showed similar outcomes. From this rest, it was possible to ascertain that the Colocasia escenta extract contains a large amount of panthenol, and that most of the efficacy of Colocasia escenta extract on inflammation wod be as a rest of the efficacy of panthenol contained in its components. Therefore, it can be assumed that using Colocasia escenta water extract will be more usef than using panthenol in terms of cost and safety. In conclusion, Colocasia escenta water extract is not only excellent in nutritional terms, but also has a good anti-inflammatory effect compared to other crops from the viewpoint of Korean medicine, suggesting that people suffering from chronic inflammation can benefit from taking it for health reasons. However, allergic reactions to taro, and nutritional imbalance and excess due to excessive consumption shod be taken note of and consumed in a proper amount and method.

\section{References}

Agyare, C., Y.D. Boakye, J.A. Apenteng, S.O. Dapaah, T. Appiah, and A. Adow. 2016. Antimicrobial and Anti-Inflammatory Properties of Anchomanes difformis (B1.) Engl. and Colocasia escenta (L.) Schott. Biochem. Pharmacol. 5(1). https://doi.org/10.4172/2167-0501.1000201

Aruna, G., B.S. Mamatha, and V. Baskaran. 2009. Lutein content of selected Indian vegetables and vegetable oils determined by HPLC. J. Food. Compost. Anal. 22(7-8):
632-636. https://doi.org/10.1016/j.jfca.2009.03.006

Andrieux, P., P. Fontannaz, T. Kilinc, and E.C. Giménez. 2012. Pantothenic Acid (Vitamin $B_{5}$ ) in Fortified Foods: Comparison of a Novel tra-Performance Liquid ChromatographyTandem Mass Spectrometry Method and a Microbiological Assay (AOAC Official Method ${ }^{\mathrm{SM}}$ 992.07). J. AOAC. Int. 95(1):143-148. https://doi.org/1 $0.5740 /$ jaoacint.10-333

Ahn, G., E.J. Park, D.S. Kim, Y.J. Jeon, T.K. Shin, J.W. Park, K.W. Lee, and Y.H. Heun. 2008. Anti-inflammatory Effects of Enzymatic Extract from Ecklonia cava on TPA-induced Ear Skin Edema. Food Sci. Biotechnol. 17(4):745-750.

Caicedo, W., J.C. Vargas, H. Uvidia, E. Samaniego, S. Valle, L. Flores. 2018. Effect of taro tubers (Colocasia escenta (L.) Schott) silage on the productive performance of commercial pigs. Technical note. Cuban. J. Agric. Sci. 52(2):1-5

Clark, M.F, R.M. Lister, and M.B. Joseph. 1986. ELISA techniques. Methods Enzymol. 118:742-766. https://doi. org/10.1016/0076-6879(86)18114-6

Eum, W. S., K. J. Lee, D. W. Kim, S. S. Lim, I. J. Kang, J.S. Park, and S.Y. Choi. 2013. Anti-inflammatory effects of extracts from Caesalpinia sappan L. on skin inflammation. J. Korean Soc. Food Sci. Nutr. 42(3): 384-388. https://doi.org/10.3746/jkfn.2013.42.3.384

Ferreres, F., R.F. Goncalves, A. Gil-Izquierdo, P. Valentao, Artur M.S. Silva, J.B. Silva, D. Santos, and P.B. Andrade. 2012. Further Knowledge on the Phenolic Profile of Colocasia escenta (L.) Shott. J. Agric. Food. Chem. 60(28):7005-7015. https://doi.org/10.1021/jf301739q

Fischer, A.H., K.A. Jacobson, J. Rose and R. Zeller. 2008. Hematoxylin and Eosin Staining of Tissue and Cell Sections. Cold. Spring. Harb. Protoc. 2008(5):pdb-prot 4986. https://doi.org/10.1101/pdb.prot4986

He, H., S. Li, H. CHen, L. Li, C. Xu, F. Ding, Y. Zhan, J. Ma, S. Zhang, Y. Shi, C. Qu and Z. Liu. 2014. 12-O-tetradecanoylphorbol-13-acetate promotes breast cancer cell motility by increasing S100A14 level in a Kruppel-like transcription factor 4 (KLF4)-dependent manner. J. Biol. Chem. 289(13):9089-9099. https://doi.org/10.1074/jbc.M113.534271

Kawase, Y., T. Hoshino, K. Yokota, A. Kuzuhara, Y. Kirii, E. Nishiwaki, Y. Maeda, J. Takeda, M. Okamoto, S. 
Kato, T. Imaizumi, H. Aizawa and K. Yoshino. 2003. Exacerbated and prolonged allergic and non-allergic inflammatory cutaneous reaction in mice with targeted interleukin-18 expression in the skin. J. Invest. Dermatol. 121(3):502-509. https://doi.org/10.1046/j.1523-1747.20 03.12407.x

Kelly, G.S. 2011. Pantothenic acid. Altern. Med. Rev. 16(3):263-274.

Kim, S.K., H.S. Lee, K.S. Byeon, Y.J. Lee, S.M. Hong, M.R. Choi, and J.W. Park. 2010. The effect of hyaluronic acid on anti-inflammatory action in mouse. J. Korean. Assoc. Oral. Maxillofac. Surg. 36(1):16-22. https://doi.org/10.5125/jkaoms.2010.36.1.16

Lomenova, A., K. Hroboňová, and T. Šolónyová. 2018. HPLC separation of panthenol enantiomers on different types of chiral stationary phases. Acta Chim Slov. 11(2): 114-119. https://doi.org/10.2478/acs-2018-0017

Madasamy, T., M. Pandiaraj, M. Balamurugan, K. Bhargava, N.K. Sethy, and C. Karunakaran, 2014. Copper, zinc superoxide dismutase and nitrate reductase coimmobilized bienzymatic biosensor for the simtaneous determination of nitrite and nitrate. Biosens. Bioelectron. 52:209-215. https://doi.org/10.1016/j.bios.2013.08.036

Muñoz-Cuervo, I., R. Malapa, S. Michalet, V. Lebot, and L. Legendre. 2016. Secondary metabolite diversity in taro, Colocasia esculenta (L.) Schott, corms. J. Food. Compost. Anal. 52:24-32. https://doi.org/10.1016/j.jfca. 2016.07.004

Muller, P.Y., H. Janovjak, A.R. Miserez, and Z. Dobbie. 2002. Processing of gene expression data generated by quantitative real-time RT-PCR. Biotechniques. 32(6): 1372-1379.

Noh, H.M., S.G. Park, W. Kim, E.H. Jo, H.H. Ki, D.K. Kim, and M.C. Park. 2017. Anti-allergic Effects of Jagamcho-tang in Ovalbumin-induced Atopic Dermatitis Mouse Model. J. Physiol. Pathol. Korean Med. 31(5): 277-283. https://doi.org/10.15188/kjopp.2017.10.31.5.277

Ogata, F. and S. Makisumi. 1984. Isolation and characterization of trypsin inhibitors from tubers of taro, Colocasia antiquorum var. nymphaifolia? J. Biochem. 96(5):1565-1574. https://doi.org/10.1093/oxfordjournals.jbchem.a134986

Ogata, F. and S. Makisumi. 1985. Subunit compositions of trypsin inhibitors from tubers of taro, Colocasia antiquorum var. nymphaifolia?. J. Biochem. 97(2):589-597. https://doi.org/10.1093/oxfordjournals.jbchem.a135094

Pan, Y.N., E.S. Park, G.H. Hong, Y.I. Lim, and K.Y. Park. 2019. Chrysophanol Suppressed the Level of ProInflammatory Cytokines Induced by LPS in Raw 264.7 Macrophage Cells. J. Korean Soc. Food Sci. Nutr. 48(12), 1323-1329. https://doi.org/10.3746/jkfn.2019.4 8.12 .1323

Park, S. N. 1999. Effect of natural products on skin cells: action and suppression of reactive oxygen species. J. Soc. Cosmet. Sci. Korea. 25(2):77-127.

Kang, W.S., S.M. Jeong, S.H, Ryu, X. Xu, J.E. Lee, and D.H. Ahn. 2020. Anti-Atopic effect of DNCB-induced mouse in chondrus canaliculatus Ethanol extracts. J Korean Soc. Food Sci. Nutr. 49(7):653-658, https://doi. org/10.3746/jkfn.2020.49.7.653

Park, T.I., H.S. Lee, H.J. Lee, C.H. Chae, Y.J Lee, K.S. Byeon, S.H. Hong, M.R. Choi and J.W Park. 2010. The Effect of ER: YAG Laser \& ER, CR: YSGG Laser on the Tissue of the Inflammation-Induced Mouse. Maxillofac. Plast. Reconstr. Surg. 32(5):396-405

Park, T.J., J.H. Sim, H.H. Hong, D.H. Han, and S.Y. Kim. 2020. Anti-inflammatory Effect of Colocasia esculenta Biorenovate Extract in LPS-stimulated RAW 264.7 Cells. Korean Soc. Biotechnol. Bioeng. J. 35(2):162-168. https://doi.org/10.7841/ksbbj.2020.35.2.162

Rael, E.L. and R.F. Lockey. 2011. Interleukin-13 signaling and its role in asthma. World Allergy Organ. J. 4(3): 54-64. https://doi.org/10.1097/WOX.0b013e31821188e0

Rashmi D.R, N. Raghu, T.S. Gopenath, P. Pradeep, B. Pugazhandhi, K. Murugesan, G. Ashok, MS. Ranjith, GK. Chandrashekrappa, and MB. Kanthesh. 2018. Taro (Colocasia esculenta): An overview. J. Med. Plants Stud. 6(4):156-161.

Song, H.Y., J.A. Lee, S.M. Ju, K.Y. Yoo, H.W. Moo, H.J. Kwon, W.S. Eum, S.H. Jang, S.Y. Choi, and J.S. Park. 2008. Topical transduction of superoxide dismutase mediated by HIV-1 Tat protein transduction domain ameliorates 12-O-tetradecanoylphorbol-13-acetate (TPA)induced inflammation in mice. Biochem. Pharmacol. 75(6):1348-1357. https://doi.org/10.1016/j.bcp.2007.11.015

Tahiliani, A.G., and C.J. Beinlich. 1991. Pantothenic Acid in Health and Disease. Vitamins and hormones 46: 165-228. https://doi.org/10.1016/S0083-6729(08)60684-6

Takahashi, K., K. Fukushima, Y. Onishi, K. Inui, Y. Node, 
N. Fukushima, K. Honoki and T. Tsujiuchi. 2017. Lysophosphatidic acid (LPA) signaling via LPA4 and LPA6 negatively regulates cell motile activities of colon cancer cells. Biochem. Biophys. Res. Commun. 483(1): 652-657. https://doi.org/10.1016/j.bbrc.2016.12.088
Tuse, T.A., U.N. Harle, and V.V. Bore. 2009. Hepatoprotective activity of Colocasia antiquorum against experimentally induced liver injury in rats. Malyasian. J. Pharm. Sci. 7(2):99-112. 